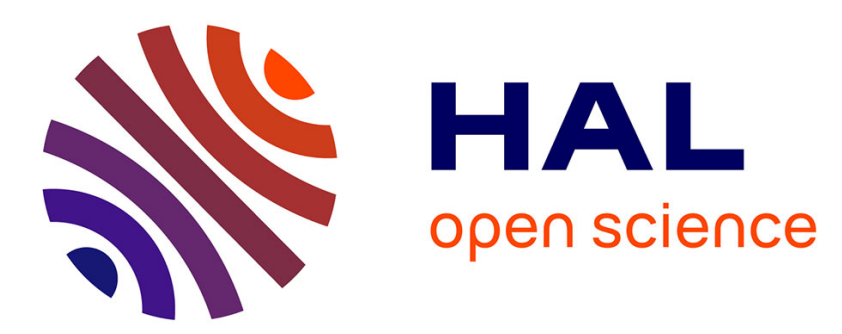

\title{
Bioaccumulation of the new antifoulant medetomidine in marine organisms
}

Annelie Hilvarsson, Cecilia Ohlauson, Hans Blanck, Åke Granmo

\section{To cite this version:}

Annelie Hilvarsson, Cecilia Ohlauson, Hans Blanck, Åke Granmo. Bioaccumulation of the new antifoulant medetomidine in marine organisms. Marine Environmental Research, 2009, 68 (1), pp.19. 10.1016/j.marenvres.2009.03.007 . hal-00487743

HAL Id: hal-00487743

https://hal.science/hal-00487743

Submitted on 31 May 2010

HAL is a multi-disciplinary open access archive for the deposit and dissemination of scientific research documents, whether they are published or not. The documents may come from teaching and research institutions in France or abroad, or from public or private research centers.
L'archive ouverte pluridisciplinaire HAL, est destinée au dépôt et à la diffusion de documents scientifiques de niveau recherche, publiés ou non, émanant des établissements d'enseignement et de recherche français ou étrangers, des laboratoires publics ou privés. 


\section{Accepted Manuscript}

Bioaccumulation of the new antifoulant medetomidine in marine organisms

Annelie Hilvarsson, Cecilia Ohlauson, Hans Blanck, Åke Granmo

PII:

S0141-1136(09)00034-8

DOI:

10.1016/j.marenvres.2009.03.007

Reference:

MERE 3327

To appear in:

Marine Environmental Research

Received Date:

12 January 2009

Revised Date:

19 March 2009

Accepted Date:

27 March 2009

Please cite this article as: Hilvarsson, A., Ohlauson, C., Blanck, H., Granmo, A., Bioaccumulation of the new antifoulant medetomidine in marine organisms, Marine Environmental Research (2009), doi: 10.1016/j.marenvres. 2009.03.007

This is a PDF file of an unedited manuscript that has been accepted for publication. As a service to our customers we are providing this early version of the manuscript. The manuscript will undergo copyediting, typesetting, and review of the resulting proof before it is published in its final form. Please note that during the production process errors may be discovered which could affect the content, and all legal disclaimers that apply to the journal pertain. 
1 Bioaccumulation of the new antifoulant medetomidine in marine

2 organisms

3 Annelie Hilvarsson ${ }^{1 *}$, Cecilia Ohlauson ${ }^{2}$, Hans Blanck $^{2} \&$ Åke Granmo ${ }^{1}$

$4 \quad{ }^{1}$ Department of Marine Ecology - Kristineberg, University of Gothenburg, Kristineberg

5 566, SE-450 34 Fiskebäckskil, Sweden

$6 \quad{ }^{2}$ Department of Plant and Environmental Sciences, University of Gothenburg, Box 461

7 SE-405 30 Gothenburg, Sweden

8

$9 \quad$ * Corresponding author: Annelie Hilvarsson tel: +46 52318556 fax: +46 52318502

10 e-mail: annelie.hilvarsson@marecol.gu.se 


\section{Abstract}

2 Biofouling is a huge problem globally and new alternative antifoulants are presently

3 being investigated. One candidate is medetomidine, a commonly used sedative in

4 veterinary medicine, which has been shown to effectively prevent settlement of barnacles.

5 The purpose of this study was to measure uptake, elimination and bioconcentration of

6 medetomidine in Mytilus edulis, Abra nitida, Crangon crangon and periphyton

7 communities to evaluate the risk of bioaccumulation in the marine environment.

8 Bioconcentration factors (BCF) and bioaccumulation factors (BAF) were used to assess

9 the bioaccumulation. The calculations of these factors were based on the distribution of

10 the radiolabelled medetomidine. BCF for Crangon crangon was 2.8 while Mytilus edulis

11 had a BCF of 134 and the periphyton communities' BCF was 1195 1/kg fresh weight

12 (FW). The concentration of medetomidine in the animals reached steady state after 24 to

1348 hours for all test systems except for Abra nitida, which never stabilised enough to

14 calculate a bioaccumulation factor (BAF). Elimination from the organism's tissues was

15 rapid for three of the test systems with half-lives between 1 and $24 \mathrm{~h}$. Abra nitida had a

16 half-life of 96-120 h. The present study demonstrates that the bioconcentration and

17 bioaccumulation of medetomidine differs between aquatic organisms and that microalgal

18 communities in the form of periphyton have the highest bioconcentration factor of the

19 organisms tested.

22 Keywords: medetomidine; antifouling substance; bioaccumulation; elimination; uptake;

23 periphyton; benthos 


\section{$1 \quad$ 1. Introduction}

2 Medetomidine (4-[1-(2,3-dimethylphenyl)ethyl]-1H-imidazole) is commonly used as a

3 sedative in veterinary medicine and functions as an $\alpha$-adrenoceptor agonist in mammals.

4 It is presently under development for use as an antifouling compound and has been

5 shown to successfully prevent settlement of barnacles at nanomolar concentrations

6 (Dahlström et al., 2000). Much is known about mammalian effects (MacDonald et al.,

7 1988; Scheinin et al., 1989; Vainio and Palmu, 1989; Kuusela et al., 2000) and

8 pharmacokinetics (Salonen, 1989; Kuusela et al., 2000; Ranheim et al., 2000) of

9 medetomidine. Effect studies have also been conducted on fish (Bellas et al., 2005;

10 Ruuskanen et al., 2005; Lennquist and Förlin, 2006; Hilvarsson et al., 2007; Lennquist et

11 al., 2008) and invertebrates (Bellas et al., 2006; Krång and Dahlström, 2006). However,

12 to our knowledge very little is known about bioaccumulation processes in aquatic

13 organisms.

14 Information on bioaccumulation and the risk of biomagnification of a chemical is

15 essential when conducting a risk assessment. Accumulation of a contaminant in the

16 aquatic environment is determined by its physical and chemical properties as well as

17 availability and persistence in water and the type of food chains exposed. The amount of

18 bioaccumulation is often correlated to the octanol-water partitioning coefficient $\left(\mathrm{K}_{\mathrm{ow}}\right)$

19 with a linear relationship between bioaccumulation and $\mathrm{K}_{\mathrm{ow}}$ for most substances below

$20 \log \mathrm{K}_{\mathrm{ow}} 6$. Highly hydrophobic substances $\left(\log \mathrm{K}_{\mathrm{ow}}>6\right)$ do not display this correlation

21 since bioaccumulation is limited by molecule size.

22 The indicators traditionally used for bioaccumulation are the bioconcentration factor

23 (BCF) or the bioaccumulation factor (BAF). The factors are used as a measure of how 
1

much of a certain contaminant an organism can absorb from the environment. BCF is defined as the ratio of the contaminant in the tissue of an organism to the concentration in the water, and $\mathrm{BAF}$ as the ratio of the contaminant in the tissue to the concentrations in any compartments (such as water, sediment, food) relevant for the main uptake routes from the environment. Both BCF and BAF are measured at steady-state conditions (Spacie et al., 1995) and most commonly presented as wet weight with the unit 1/kg (Arnot and Gobas 2006) which is also used throughout this article. The criteria set by the European Chemicals Bureau for BCF states that a substance with a value above 2000 is bioaccumulative (Technical Guidance Document on Risk Assessment EUR 20418 EN/2). However, there are many more assessment endpoints from regulatory agencies such as the US Environmental Protection Agency, Environment Canada and the United Nations with BCF values ranging from 1000 to 5000 (Arnot and Gobas, 2006). These values do however only concern wet weight that causes some problems when working with systems like periphyton communities that are commonly measured as dry weight due to a high proportion of interstitial water. A BCF based on dry weight gives extremely high values and cannot be compared with fresh weight based BCFs. One way to normalise this difference is to express all values as lipid weight based concentrations since lipid content is one of the most important factors determining uptake of lipophilic compounds. Other factors like the amount of organic carbon in the organisms can however also influence accumulation, especially for primary producers. Normalisation to lipid content would then cause an overestimation of the bioaccumulation so to choose a normalisation method that suite all test species or systems can be difficult (Berglund et al., 2005). In this study no normalisations were performed. 
Medetomidine has a QSPR-estimated $\log \mathrm{K}_{\mathrm{ow}}$ of 3.13 ( $\mathrm{pH}$ 8, QSPR (Quantitative

2 Structure Pharmacokinetic Relationship)). It is intermediately hydrophobic and may

3 bioaccumulate $\left(\log \mathrm{K}_{\mathrm{ow}}>3\right.$ ) according to the Technical Guidance Document on Risk

4 Assessment (EUR 20418 EN/2). Because of the imidazole group in medetomidine, a

5 substantial amount of the compound is likely to be adsorbed to sediment particles

6 (Sundberg and Martin, 1974; Handa et al., 2006) and might therefore constitute a risk

7 especially to sediment-living and sediment-eating organisms. However, a $\log \mathrm{K}_{\mathrm{ow}}$ below

84.5 is not enough to classify a substance to be bioaccumulative based on $\mathrm{K}_{\mathrm{ow}}$ values alone

9 (Technical Guidance Document on Risk Assessment EUR 20418 EN/2).

10 The present study aims to investigate the bioaccumulation of medetomidine in a selection

11 of marine aquatic species to increase the knowledge of the substance behaviour. The

12 different test organisms are chosen to get a broad understanding on the potential

13 accumulation in the marine environment, from microbiota in periphyton communities, to

14 filter- (blue mussel, Mytilus edulis) and sediment-feeders (Abra nitida). A crustacean, the

15 brown shrimp (Crangon crangon), was also included since medetomidine is known to

16 have effects on other crustaceans, i.e. barnacles. They were also selected because they are

17 key species in their individual habitats and very abundant (Wikander 1980; Pihl and

18 Rosenberg 1982; Gosling 1992).

19 This study is part of a larger risk assessment study of medetomidine conducted within the

20 research programme Marine Paint funded by the Swedish Foundation for Environmental

21 Research (MISTRA).

\section{2. Materials \& methods}




\subsection{Biological material}

2 Periphyton growing on glass discs $\left(1.5 \mathrm{~cm}^{2}\right)$ mounted on polyethylene holders (Blanck and Wängberg, 1988) were sampled from the coastal environment. The glass discs were gently cleaned with paper tissues on all sides except the colonized one and sorted to achieve a homogenous set of glass discs for uptake and elimination studies.

6 Blue mussels, Mytilus edulis, with an average length of $30 \mathrm{~mm}( \pm 5 \mathrm{~mm})$ were collected by hand at a depth of approximately 0.5-1 m. Brown shrimps, Crangon crangon, with an average length of $30 \mathrm{~mm}( \pm 5 \mathrm{~mm})$ were collected using a push-net at a depth of approximately $1 \mathrm{~m}$.

10 Periphyton, Mytilus edulis and Crangon crangon were collected from bays nearby Sven

11 Lovén Centre for marine sciences (formerly Kristineberg Marine Research Station) at the

12 Gullmarsfjord, on the west coast of Sweden. Abra nitida with an average length of 13

$13 \mathrm{~mm}( \pm 1 \mathrm{~mm})$ and sediment (silty clay $>85 \%<4 \mu \mathrm{m}$, TOC $4 \%$ ) were collected using a

14 benthic sledge (Warén) from a depth of approximately $100 \mathrm{~m}$ in the Gullmarsfjord.

\subsection{Experimental solutions}

17 Medetomidine was ${ }^{14} \mathrm{C}$-labelled in the methyl group directly bound to the chiral carbon.

18 The specific activity was $0.51 \mathrm{GBq} / \mathrm{mmol}$. It was synthesised using ${ }^{14} \mathrm{C}$-labelled alkyl

19 substituted bromobenzene as starting material to prepare a Grignard reagent and supplied

20 by the Marine Paint Formulation project. The medetomidine stock solution was dissolved

21 in ethanol and experimental solutions were made by dissolving the stock solution in

22 filtered seawater (GF/F for periphyton, $12 \mu \mathrm{m}$ for the other test species) to a nominal

23 concentration of $20 \mu \mathrm{g} / \mathrm{l}(100 \mathrm{nM})$. The concentration was chosen to achieve a ${ }^{14} \mathrm{C}$-level 
1

13 Exposure of periphyton communities to ${ }^{14} \mathrm{C}$-labelled medetomidine was performed in 14 glass containers $(10 \times 15 \times 5 \mathrm{~cm})$ with $300 \mathrm{ml}$ of test medium placed on a shaker $(60 \mathrm{rpm})$ at sampled disc was immediately rinsed by quickly dipping it in water three times to

above the detection limit but below a medetomidine concentration that cause physiological effects in the test organisms. The concentration is not related to predicted environmental concentrations (PEC), it is approximately 5000 times higher than PEC values derived by modeling (unpublished data, Ohlauson C).

\subsection{Spiking of sediment}

Sediment was spiked by mixing $1.5 \mathrm{~kg}$ (wet weight) of sieved sediment $(0.5 \mathrm{~mm}$ mesh size) with 1.51 of experimental medetomidine solution. The mixture was rotated in darkness $\left(15^{\circ} \mathrm{C}\right)$ for $24 \mathrm{~h}$ in a tumbler (Rotary tumbler Model QT66, Lortone, inc., Seattle, WA) before start of the experiment.

\subsection{Exposure and sampling} $25 \mu \mathrm{mol}$ photons $\mathrm{x} \mathrm{m}^{-2} \mathrm{x} \mathrm{s}^{-1}$ with a 13:9 light dark regime and a constant temperature of $\left.18^{\circ} \mathrm{C}\right)$. Five replicate containers were used each with 20 discs. After 48 hours of uptake the discs were rinsed and transferred to clean containers with uncontaminated water for another 48 hours to study elimination. To avoid reuptake of ${ }^{14} \mathrm{C}$-labelled medetomidine the water was changed again after 30 minutes. All solutions were changed every 24 hours. Samples were taken after 30 s, 1, 16 and $32 \min (n=3)$ and at 1, 4, 8, 16, 24 and 48 hours $(\mathrm{n}=5)$, both during exposure to ${ }^{14} \mathrm{C}$-medetomidine and uncontaminated water. The eliminate ${ }^{14} \mathrm{C}$-medetomidine trapped in the interstitial water. The disc was then put into a 
1

2

3

4

$20 \mathrm{ml}$ glass scintillation vial with the periphyton-colonised side upwards. Since fresh weight is difficult to estimate with good precision due to trapped interstitial water periphyton dry weight was measured at time 0 and after 48 hours in uncontaminated water $(n=3)$. Discs were dried to constant weight $( \pm 1 \%)$ at $70^{\circ} \mathrm{C}$ and weighed. The periphyton biofilm was dissolved by incubating each disc in $0.5 \mathrm{ml} \mathrm{HNO}_{3}$ at $100^{\circ} \mathrm{C}$ for 30 minutes. When the samples reached room temperature $0.5 \mathrm{ml} \mathrm{H}_{2} \mathrm{O}_{2}$ was added and the discs were incubated at $100^{\circ} \mathrm{C}$ for $30-60$ minutes. The clean glass discs were rinsed in deionised water, dried in a fume hood and weighed again. When needed, periphyton dry weight was transformed to wet weight by multiplying with a factor of 12.5 (Sladecek and Sladeckova 1963; Sladecek and Sladeckova 1964).

For the Crangon, Mytilus and Abra experiments, three replicates were used as well as controls without medetomidine to control for mortality throughout the experimental period. Mytilus edulis and Crangon crangon were exposed to ${ }^{14} \mathrm{C}$-labelled medetomidine for 8 days in glass or plexiglass aquaria containing 2.51 of experimental solution. The shrimps were individually separated in order to avoid cannibalism. No sediment or bottom gravel was added. Following exposure, they were kept in uncontaminated filtered seawater for an elimination period of 5 days. Solutions were changed every 24 hours. Temperature was kept constant at $15^{\circ} \mathrm{C}$ and a $14: 10$ light dark regime was used. Samples were taken at 0,1 day, 2, 4, 6, and 8 days of exposure and following 6 and $12 \mathrm{~h}, 1$ day, 2, 3 and 5 days in uncontaminated water for the Mytilus experiment and at 0,1 day, 2, 4, 6, and 8 days of exposure and following $6 \mathrm{~h}, 1$ day, 2, 3 and 5 days in uncontaminated water for the Crangon experiment. Abra nitida was exposed to ${ }^{14} \mathrm{C}$-labelled medetomidine for 2 
days in glass aquaria containing one third of the spiked water-sediment mixture $(0.5 \mathrm{~kg}$ sediment and 0.51 experimental solution). Following exposure they were kept in uncontaminated filtered seawater and sediment for an elimination period of 5 days. Experimental solutions were not changed during the exposure period of 48 hours but during the elimination phase water was changed every 24 hours. Temperature was kept constant at $10^{\circ} \mathrm{C}$ and a $14: 10$ light dark regime was used. Samples were taken at $0,3,6$ and $12 \mathrm{~h}, 1$ and 2 days of exposure and following 3, 6 and 12 h, 1, 2, 3, 4 and 5 days in uncontaminated water. One specimen was taken from each replicate at each sampling occasion.

\subsection{Tissue preparation}

12 Periphyton samples were prepared for scintillation counting in a similar way as for

13 photosynthesis measurements (Blanck and Wängberg, 1988) i.e. dissolved with $1 \mathrm{ml}$ of

14 dimethylsulfoxide and left for at least $10 \mathrm{~min}$ before adding $9 \mathrm{ml}$ of scintillation cocktail

15 (Ready Safe ${ }^{\mathrm{TM}}$, Beckman Instruments). Vials were shaken vigorously to obtain

16 homogeneous samples prior to scintillation counting the next day. For brown shrimp and

17 Abra nitida whole animals, without exoskeleton or shells, were used. The soft tissue from

18 blue mussel was homogenised and a subsample of approximately $150 \mathrm{mg}$ from each

19 mussel was used. The tissue of the experimental animals was placed in scintillation vials

20 and $2 \mathrm{ml}$ of Soluene ${ }^{\circledR}$ (PerkinElmer) was added to each sample. All vials were placed in

21 an incubator $\left(50^{\circ} \mathrm{C}\right.$, Heidolph incubator 1000 polymax 1040) and gently revolved until

22 the tissue was completely dissolved. $10 \mathrm{ml}$ of scintillation cocktail (Hionic-Flour, 
1 PerkinElmer) were added, samples were shaken and allowed to stand over night before

2 scintillation counting.

\subsection{Water and sediment samples}

5 From the periphyton experiment water samples were taken for scintillation counting (0.5

$6 \mathrm{ml})$ at $1,16,32 \mathrm{~min}$ and $1,4,8,16,24$ and 48 hours $(\mathrm{n}=1)$, both during exposure to ${ }^{14} \mathrm{C}$ -

7 medetomidine and uncontaminated water. $9 \mathrm{ml}$ of scintillation cocktail (Ready Safe ${ }^{\mathrm{TM}}$,

8 Beckman Instruments) was then added to each sample.

9 Water samples $(2 \mathrm{ml})$ for later scintillation counting were also taken from the Mytilus and

10 Crangon experiments at the start of the experiment and after 1 day (before solution

11 change), 1 day (after solution change), 2, 3, 4, 5, 6, 7 and 8 days ( $\mathrm{n}=3)$ and from the $A b r a$

12 experiment, at the start of the experiment and after 1 and 2 days $(n=3)$. Sediment samples

$13(100 \mathrm{mg})$ were taken at the start of the experiment and after 1 and 2 days $(\mathrm{n}=3) .10 \mathrm{ml}$ of

14 scintillation cocktail (Insta-gel Plus, Chemical Instruments) were added to water and

15 sediment samples. All samples were shaken and allowed to stand over night before

16 scintillation counting.

18 3. Results

19 The concentration of ${ }^{14} \mathrm{C}$-labelled medetomidine reached steady state in the periphyton

20 communities after 48 hours with a rapid uptake during the first 8 hours of exposure

21 followed by a stabilisation after 24 hours (Figure 1). After the first 8 hours the

22 concentration in periphyton was $15.5 \mu \mathrm{g} / \mathrm{g}$ fresh weight (FW) $(77.2 \mathrm{nmoles} / \mathrm{g})$ and at

23 steady state the concentration was $22.7 \mu \mathrm{g} / \mathrm{g}$ FW (113 nmoles/g). Mean water 
concentration was $19.0 \mu \mathrm{g} / \mathrm{l}(94.6 \mathrm{nM})$ during the uptake phase of the experiment, giving a bioconcentration factor of 1195 and 14941 if presented as 1/kg dry weight (Table 1 and

3 Figure 5). Elimination was much faster than the uptake with a half-life of less than 1

4 hour. The steady state level reached was $2.80 \mu \mathrm{g} / \mathrm{g} \mathrm{FW}(14.0 \mathrm{nmoles} / \mathrm{g})$ in periphyton 5 giving a BCF of 722 at the end of the elimination period.

6 Steady state was reached within 24 hours of exposure for both Mytilus edulis (Figure 2)

7 and Crangon crangon (Figure 3). The bioconcentration factor at the end of exposure is

8 calculated to 134 and 2.8 respectively (Table 1). BCF did not change significantly over

9 time (24 hours till 8 days) for either Mytilus or Crangon (Figure 6). Elimination of

10 medetomidine was also rapid with a half-life of less than $6 \mathrm{~h}$ in Mytilus and 6-24 $\mathrm{h}$ in

11 Crangon. The mean water concentration was $19.2 \mu \mathrm{g} / \mathrm{l}(95.8 \mathrm{nM})$ in the Mytilus

12 experiment and $16.0 \mu \mathrm{g} / \mathrm{l}(80.0 \mathrm{nM})$ in the Crangon experiment. The tissue concentration

13 in Crangon is lower on a few sampling occasions (48 and $96 \mathrm{~h}$ ) compared to after $24 \mathrm{~h}$

14 exposure because of a lower water concentration than expected, but increased as soon as

15 the water concentration increased (Figure 3). However, BCF values were stable between

$16 \quad 1.5$ and 2.8 (Figure 6). The concentration of medetomidine in the tissue of Abra nitida

17 has probably not reached steady state after the exposure period of 48 hours (Figure 4 and

18 5), thus a correct BAF cannot be calculated. However, a ratio of the concentration in

19 tissue after 48 hours and the concentration in all compartments (sediment and water)

20 gives a factor of 2.6. This might be an underestimation compared to a true BAF for Abra

21 nitida. The elimination half-life of medetomidine is approximately $96-120 \mathrm{~h}$ in Abra

22 (Table 1). The mean water concentration in the Abra experiment was $0.55 \mu \mathrm{g} / 1(2.75 \mathrm{nM})$ 

species when exposed to nonylphenol (Ekelund et al., 1990), demonstrating again that

and the mean sediment concentration $18.1 \mu \mathrm{g} / \mathrm{kg}$ (90.6 nmoles/g) demonstrating medetomidine's ability to adsorb to sediment particles.

No significant mortality $(<5 \%)$ and no difference between controls and treatments were observed in any of the experiments.

\section{Discussion}

Medetomidine is shown to have a maximal bioconcentration factor of 1195, which occurred in periphyton at steady state. The rate of uptake is quite high in periphyton communities compared to other test species. This is probably due to periphyton's large surface area and high lipid content (Wang et al., 1999). Whether medetomidine is rapidly mobile in and out of the essentially unicellular periphyton organisms, or only adsorbed to the surface cannot be conclusively clarified in the present study. However, the fit to a two-compartment bioconcentration model (Newman, 1995) is consistent with a surface adsorption with a rapid first phase followed by a secondary slower accumulation (data not shown). The rapid elimination $\left(\mathrm{t}_{1 / 2}<1 \mathrm{~h}\right)$ implies as well that most of the medetomidine is adsorbed and only a small fraction is taken up by the algal cells since the concentration decreased immediately when exposure ended. The medetomidine remaining in periphyton after 48 hours is 79 nmoles/g dry weight corresponding to 2.3 pmoles per square centimeter.

For brown shrimp a considerably lower bioconcentration factor (2.8) is found compared to blue mussel (BCF 134). A similar result has previously been observed in these two bioaccumulation is species dependent, with a BCF of 100 for brown shrimp and 3400 for 
blue mussel. As a consequence, bioaccumulation should always be studied in several species to get the full range of possible bioconcentration and bioaccumulation factors. The experiment with Abra nitida suggests that it may take longer time to reach a steadystate condition in sediment systems and the elimination of medetomidine also seems to be slower. One possible explanation for the slower uptake of medetomidine in A. nitida, compared to the other species tested, might be because of medetomidine's ability to interact with surrounding molecules, e.g. metals in the sediment (Sundberg and Martin, 1974), and might therefore be transported through the gut of the organisms without being readily absorbed by the tissues. Further experiments with longer exposure periods and other sediment-eating organisms are needed to validate the results from this study which indicates that only minor uptake of medetomidine is through the sediment. However, the concentration used in the present study $(20 \mu \mathrm{g} / \mathrm{l}, 100 \mathrm{nM})$ may have been high enough to impair the bivalves feeding behaviour thus decreasing the uptake of medetomidine. Earlier studies have shown a decreased sediment reworking activity already at $10 \mathrm{nM}$ but the amount of faeces produced were however not affected up to $375 \mathrm{nM}$ indicating that the bivalves fed normally, but at a different layer in the sediment, when exposed to medetomidine (Bellas et al., 2006). The animals used in the present study buried into the sediment and stayed buried throughout the experiment. However, feeding activity was not measured and the sediment was not removed from the gut prior to analysis.

Our results show, in agreement with mammalian data, a rapid uptake and elimination of the ${ }^{14} \mathrm{C}$-labelled molecule in all test organisms, except for Abra. Medetomidine is biotransformed in the hepatic tissue in mammals and not more than $5 \%$ is excreted as unchanged medetomidine (Salonen, 1989). In vitro studies in rat show that medetomidine 
1

only have one major metabolite, hydroxymedetomidine, while three major metabolites and some minor metabolites were found in vivo. Two different pathways are suggested after hydroxylation and they depend on the concentration of medetomidine. None of the major metabolites have areceptor activity, thus this transformation removes the active molecule (Salonen and Eloranta, 1990). However, the study indicates that methylation might occur to a very minor extent which could produce a metabolite that would be slowly eliminated and thus accumulate in fatty tissues during long time exposure (Salonen and Eloranta, 1990). Metabolites are not analysed in the present study and it cannot be entirely excluded that a small amount of the N-methylated conjugate is formed.

Further studies with collection of excretion products and analysis of metabolites are needed to investigate whether this potentially bioaccumulating metabolite is produced in invertebrates as well. The medetomidine used in this experiment was also only ${ }^{14} \mathrm{C}$ labelled in one position, which makes it impossible to distinguish between intact medetomidine and metabolites containing the labelled carbon. For further studies medetomidine with several ${ }^{14} \mathrm{C}$-labels will be used.

A comparison of medetomidine to other antifouling substances regarding bioaccumulative potential displayed varying results. Tributyltin, TBT, which was prohibited for use in 2008 due to the environmental damages caused by the substance (Champ, 2003), has a octanol-water partitioning coefficient in the same range as medetomidine with $\log \mathrm{K}_{\mathrm{ow}}$ of 3.74 (Laughlin et al., 1986 ). BCF for TBT was also in the same range as for medetomidine regarding algae with values above 1000. For filtrating molluscs the BCF for TBT was however much higher, with values above 100000 reported (Ranke and Jastorff 2000 and references therein). Studies have also 
demonstrated that $\log \mathrm{K}_{\mathrm{ow}}$ is not a good predictor of bioconcentration or bioaccumulation for TBT with experiments resulting in much higher BCF or BAF than predicted (Huang and Wang, 1995). Another antifouling biocide, Irgarol 1051, have $\log \mathrm{K}_{\mathrm{ow}}$ values between 2.8 and 3.95 recorded. Like TBT and medetomidine Irgarol also has a rather high affinity for algae and water plants with BCFs of at least 1000 published. Other organism groups have lower BCFs for Irgarol, with values around 200 reported for fish (Ranke and Jastorff, 2000 and references therein). Both TBT and Irgarol are good examples that $\log \mathrm{K}_{\mathrm{ow}}$ does not display the full risk of bioaccumulation of a substance.

9 Experimental studies of several organism groups are necessary to separate substances

10 with a high potential to accumulate from the other non-accumulative substances with 11 similar octanol-water partitioning coefficients.

\section{5. Conclusion}

14 Medetomidine seems to be a new antifouling compound with rapid elimination and a

15 BCF below the bioaccumulative classification level $(\mathrm{BCF}<2000)$ set by the European

16 Chemicals Bureau (Technical Guidance Document on Risk Assessment EUR 20418

17 EN/2). However, further studies on degradation and metabolites are necessary before a 18 complete risk assessment can be produced.

\section{Acknowledgements}

21 We wish to thank Magnus Nydén and Paul Handa in the Marine Paint Formulation

22 project for providing us with medetomidine. Emma Nohrén and Linda Svanberg are 23 acknowledged for technical assistance and Thomas Backhaus for periphyton curve 
modelling. The research was funded through the research programme Marine Paint, by the Swedish Foundation for Strategic Environmental Research, MISTRA. Additional

3 grants were received from Birgit and Birger Wåhlström foundation.

4 


\section{References}

Arnot, J.A., Gobas, F., 2006. A review of bioconcentration factor (BCF) and bioaccumulation factor (BAF) assessments for organic chemicals in aquatic organisms. Environmental Reviews 14, 257-297.

Bellas, J., Hilvarsson, A., Granmo, A., 2005. Sublethal effects of a new antifouling candidate on lumpfish (Cyclopterus lumpus L.) and Atlantic cod (Gadus morhua L.) larvae. Biofouling 21, 207-216.

Bellas, J., Hilvarsson, A., Birgersson, G., Granmo, Å., 2006. Effects of medetomidine, a novel antifouling agent, on the burrowing bivalve Abra nitida (Müller). Chemosphere $65,575-582$.

Berglund, O., Nyström, P., Larsson, P., 2005. Persistent organic pollutants in river food webs: influence of trophic position and degree of heterotrophy. Canadian Journal of Fisheries and Aquatic Sciences 62, 2021-2032.

Blanck, H., Wängberg, S.A., 1988. Validity of an ecotoxicological test system - shortterm and long-term effects of arsenate on marine periphyton communities in laboratory systems. Canadian Journal of Fisheries and Aquatic Sciences 45, 1807 1815.

Champ MA., 2003. Economic and environmental impacts on ports and harbors from the convention to ban harmful marine anti-fouling systems. Marine Pollution Bulletin. 46(8), 935-940.

Dahlström, M., Mårtensson, L.G.E., Jonsson, P.R., Arnebrant, T., Elwing, H., 2000. Surface active adrenoceptor compounds prevent the settlement of cyprid larvae of Balanus improvisus. Biofouling 16, 191-203.

Ekelund, R., Bergman, Å., Granmo, Å., Berggren, M., 1990. Bioaccumulation of 4nonylphenol in marine animals - a re-evaluation. Environmental Pollution 64, 107120.

Gosling, E., 1992. The mussel Mytilus: Ecology, physiology, genetics and culture. Elsevier, Amsterdam.

Huang, G., Wang, Y., 1995. Effects on tributyltin chloride on marine bivalve mussels. Water Research 29(8), 1877-1884.

Handa, P., Fant, C., Nyden, M., 2006. Antifouling agent release from marine coatings-ion pair formation/dissolution for controlled release. Progress in Organic Coatings 57, 376-382.

Hilvarsson, A., Halldórsson, H.P., Granmo, A., 2007. Medetomidine as a candidate antifoulant: Sublethal effects on juvenile turbot (Psetta maxima L.). Aquatic Toxicology 83(3), 238-246.

Krång, A.-S., Dahlström, M., 2006. Effects of a candidate antifouling compound (medetomidine) on pheromone induced mate search in the amphipod Corophium volutator. Marine Pollution Bulletin 52, 1776-1783. 
Kuusela, E., Raekallio, M., Anttila, M., Falck, I., Mölsä, S., Vainio, O., 2000. Clinical effects and pharmacokinetics of medetomidine and its enantiomers in dogs. Journal of Veterinary Pharmacology and Therapeutics 23, 15-20.

Laughlin, R.B., Guard, H.E., Coleman III, W.M., 1986. Tributyltin in seawater: speciation and octanol-water partitioning coefficient. Environmental Science and Technology 20(2), 201-204.

Lennquist, A., Förlin, L., 2006. Alteration of CYP1A activity in fish as a response to medetomidine exposure. Marine Environmental Research 62, S72-S73.

Lennquist, A., Celander, M.C., Förlin, L., 2008. Effects of medetomidine on hepatic EROD activity in three species of fish. Ecotoxicology and Environmental Safety 69(1), 74-79.

MacDonald, E., Scheinin, H., Scheinin, M., 1988. Behavioural and neurochemical effects of medetomidine, a novel veterinary sedative. European Journal of Pharmacology 158, 119-127.

Newman, M.C., 1995. Quantitative methods in aquatic ecotoxicology. Lewis Publishers, cop., Boca Raton, Fla.

Pihl, L., Rosenberg, R., 1982. "Production, abundance, and biomass of mobile epibenthic marine fauna in shallow waters, Western Sweden." Journal of Experimental Marine Biology and Ecology 57: 273-301.

Ranheim, B., Arnemo, J.M., Stuen, S., Horsberg, T.E., 2000. Medetomidine and atipamezole in sheep: disposition and clinical effects. Journal of veterinary Pharmacology and Therapeutics 23, 401-404.

Ranke, J., Jastorff, B., 2000. Multidimensional risk analysis of antifouling biocides. Environmental Science and Pollution Research 7(2), 105-114.

Ruuskanen, J.O., Peitsaro, N., Kaslin, J.V.M., Panula, P., Scheinin, M., 2005. Expression and function of $\alpha$-adrenoceptors in zebrafish: drug effects, mRNA and receptor distributions. Journal of Neurochemistry 94, 1559-1569.

Salonen, J.S., 1989. Pharmacokinetics of medetomidine. Acta Veterinaria Scandinavica $85,49-54$.

Salonen, J.S., Eloranta, M., 1990. Biotransformation of medetomidine in the rat. Xenobiotica 20, 471-480.

Scheinin, H., Virtanen, R., MacDonald, E., Lammintausta, R., Scheinin, M., 1989. Medetomidine - a novel $\alpha$-adrenoceptor agonist: A review of its pharmacodynamic effects. Progress in Neuro-Psychopharmacology and Biological Psychiatry 13, 635651.

Sladecek, V., Sladeckova, A., 1963. Relationship between wet weight and dry weight of the periphyton. Limnology and Oceanography 8, 309-311.

Sladecek, V., Sladeckova, A., 1964. Determination of the periphyton production by means of the glass slide method. Hydrobiologia 23, 125-158. 


9

Spacie, A., McCarty, L.S., Rand, G.M., 1995. Bioaccumulation and bioavailability in multiphase systems. In: Rand, G.M. (Ed.), Fundamentals of aquatic toxicology: Effects, environmental fate, and risk assessment. Taylor \& Francis, Washington D.C., pp. 493-521.

Sundberg, R.J., Martin, R.B., 1974. Interactions of histidine and other imidazole derivatives with transition metal ions in chemical and biological systems. Chem. Rev. 74, 471-517.

Technical Guidance Document on Risk Assessment Part II. 2003. EUR 20418 EN/2. Institute for Health and Consumer Protection, European Chemicals Bureau, European Commission.

Vainio, O., Palmu, L., 1989. Cardiovascular and respiratory effects of medetomidine in dogs and influence of anticholinergics. Acta veterinaria Scandinavica 30, 401-408.

Wang, H., Kostel, J.A., Amand, A.L.S., Gray, K.A., 1999. 2. The response of a laboratory stream system to PCB exposure: Study of periphytic and sediment accumulation patterns. Water Research 33, 3749-3761.

Wikander, P.B., 1980. Biometry and behaviour in Abra nitida (Müller) and A. longicallus (Scacchi) (Bivalvia, Tellinacea). Sarsia 65, 255-268. 
$1 \quad$ Figure captions

$2 \quad$ Figure 1

3 Bioaccumulation in periphyton communities exposed to a nominal concentration of 20

$4 \mathrm{~g} / \mathrm{l}(100 \mathrm{nM})$ of medetomidine. $\bullet$ tissue concentration of medetomidine during exposure

$5 \Delta$ tissue concentration of medetomidine during elimination $\square$ water concentration of

6 medetomidine.

8 Figure 2

9 Bioaccumulation in Mytilus edulis exposed to a nominal concentration of $20 \mathrm{~kg} / \mathrm{l}$ (100

$10 \mathrm{nM}$ ) of medetomidine. tissue concentration of medetomidine during exposure $\Delta$ tissue

11 concentration of medetomidine during elimination $\square$ water concentration of

12 medetomidine during exposure. Data show the median value $+/$ - range $(n=3)$.

\section{$14 \quad$ Figure 3}

15 Bioaccumulation in Crangon crangon exposed to a nominal concentration of $20 \mu \mathrm{g} / \mathrm{l}$ (100

$16 \mathrm{nM}$ ) of medetomidine. $\bullet$ tissue concentration of medetomidine during exposure $\Delta$ tissue

17 concentration of medetomidine during elimination $\square$ water concentration of

18 medetomidine during exposure. Data show the median value $+/$ - range $(n=3)$.

$20 \quad$ Figure 4

21 Bioaccumulation in Abra nitida exposed to a nominal concentration of $20 \mathrm{~g} / \mathrm{l}(100 \mathrm{nM})$

22 of medetomidine. tissue concentration of medetomidine during exposure $\Delta$ tissue 
1 concentration of medetomidine during elimination $\square$ total concentration of medetomidine

2 in the sediment and water during exposure. Data show the median value $+/$ - range $(n=3)$.

4 Figure 5

5 Bioaccumulation in periphyton and Abra nitida exposed to a nominal concentration of 20

$6 \mathrm{~g} / \mathrm{l}(100 \mathrm{nM})$ of medetomidine. $\mathrm{O}$ Periphyton BCF during exposure $\boldsymbol{\square}$ a ratio of the

7 concentration in tissue and the concentration in all compartments (sediment and water)

8 during exposure for Abra nitida. Data show the median value + /- range (Abra $\mathrm{n}=3$,

9 periphyton $\mathrm{n}=5)$.

10

11 Figure 6

12 Bioaccumulation in Crangon crangon and Mytilus edulis exposed to a nominal

13 concentration of $20 \mu \mathrm{g} / \mathrm{l}(100 \mathrm{nM})$ of medetomidine. O Crangon crangon BCF during

14 exposure Mytilus edulis BCF during exposure. Data show the median value +/- range $15 \quad(n=3)$.

16

17

18

19

20 
Table 1

Bioconcentration factors in organisms exposed to medetomidine.

\begin{tabular}{|c|c|c|c|c|}
\hline Parameter & Communit & /Species & & \\
\hline & Periphyton & Mytilus edulis & Abra nitida & Crangon crangon \\
\hline $\begin{array}{l}\text { Mean medetomidine } \\
\text { conc. in water }(\mu \mathrm{g} / \mathrm{l})\end{array}$ & 19.0 & 19.2 & 0.55 & 16.0 \\
\hline $\begin{array}{l}\text { Mean medetomidine } \\
\text { conc. in sediment }(\mu \mathrm{g} / \mathrm{kg})\end{array}$ & - & - & 18.1 & \\
\hline $\begin{array}{l}\text { Conc. of medetomidine in } \\
\text { tissue at end of exposure } \\
(\mu \mathrm{g} / \mathrm{g} F W)\end{array}$ & 22.66 & 2.54 & & 0.044 \\
\hline $\begin{array}{l}\text { Bioconcentration factor } \\
(1 / \mathrm{kg} \mathrm{FW})\end{array}$ & $\begin{array}{l}1195 \\
(14941)^{b}\end{array}$ & 134 & $2.6^{\mathrm{c}}$ & 2.8 \\
\hline Estimated half-life $t_{1 / 2}(h)$ & $<1$ & $<6$ & $96-120$ & $6-24$ \\
\hline
\end{tabular}

${ }^{a}$ for periphyton communities, Mytilus edulis and Crangon crangon steady-state was reached within the exposure period but probably not for Abra nitida

based on dry weight

bioaccumulation factor calculated without steady-state reached 
Figure 1

Figure 1

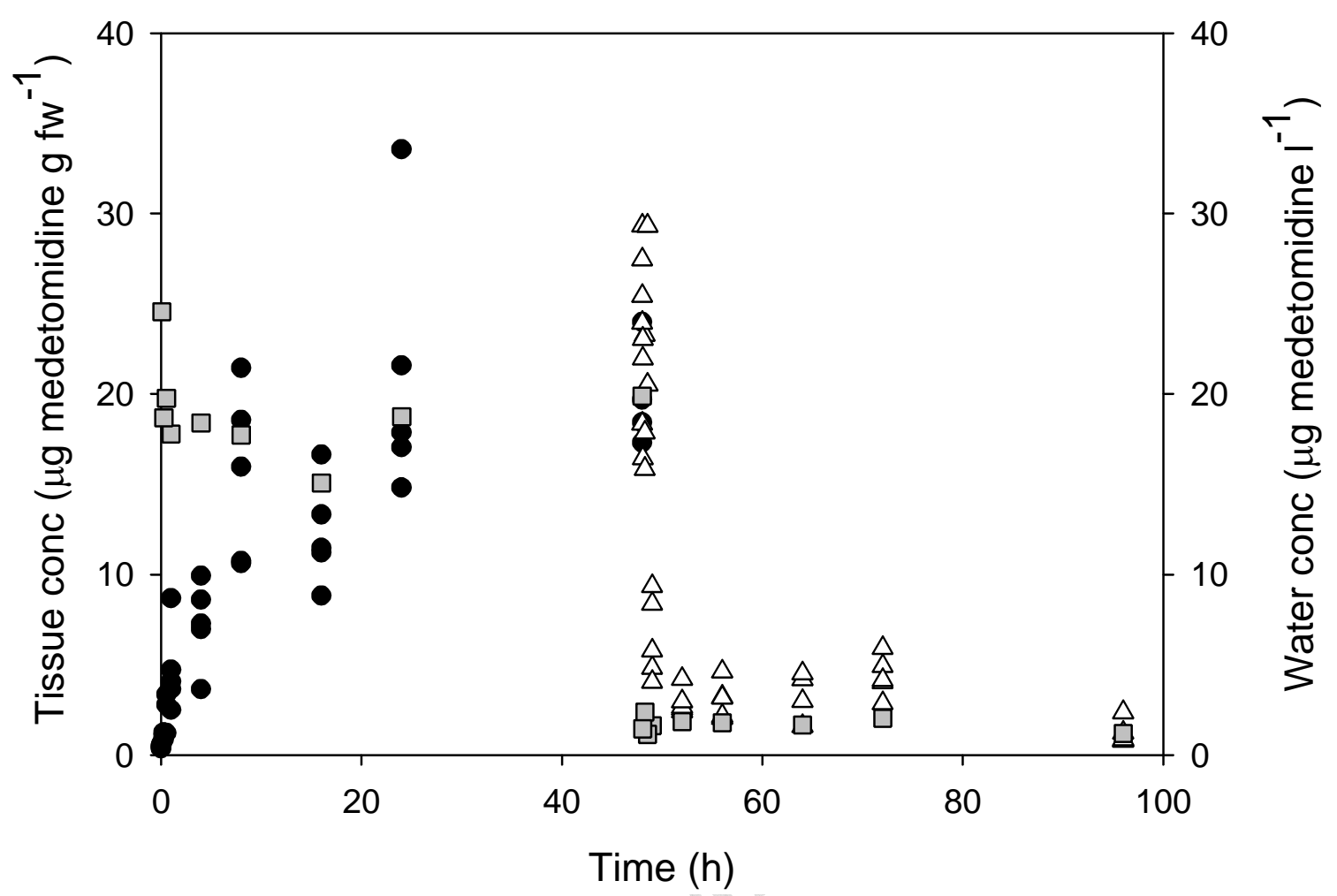


Figure 2

Figure 2

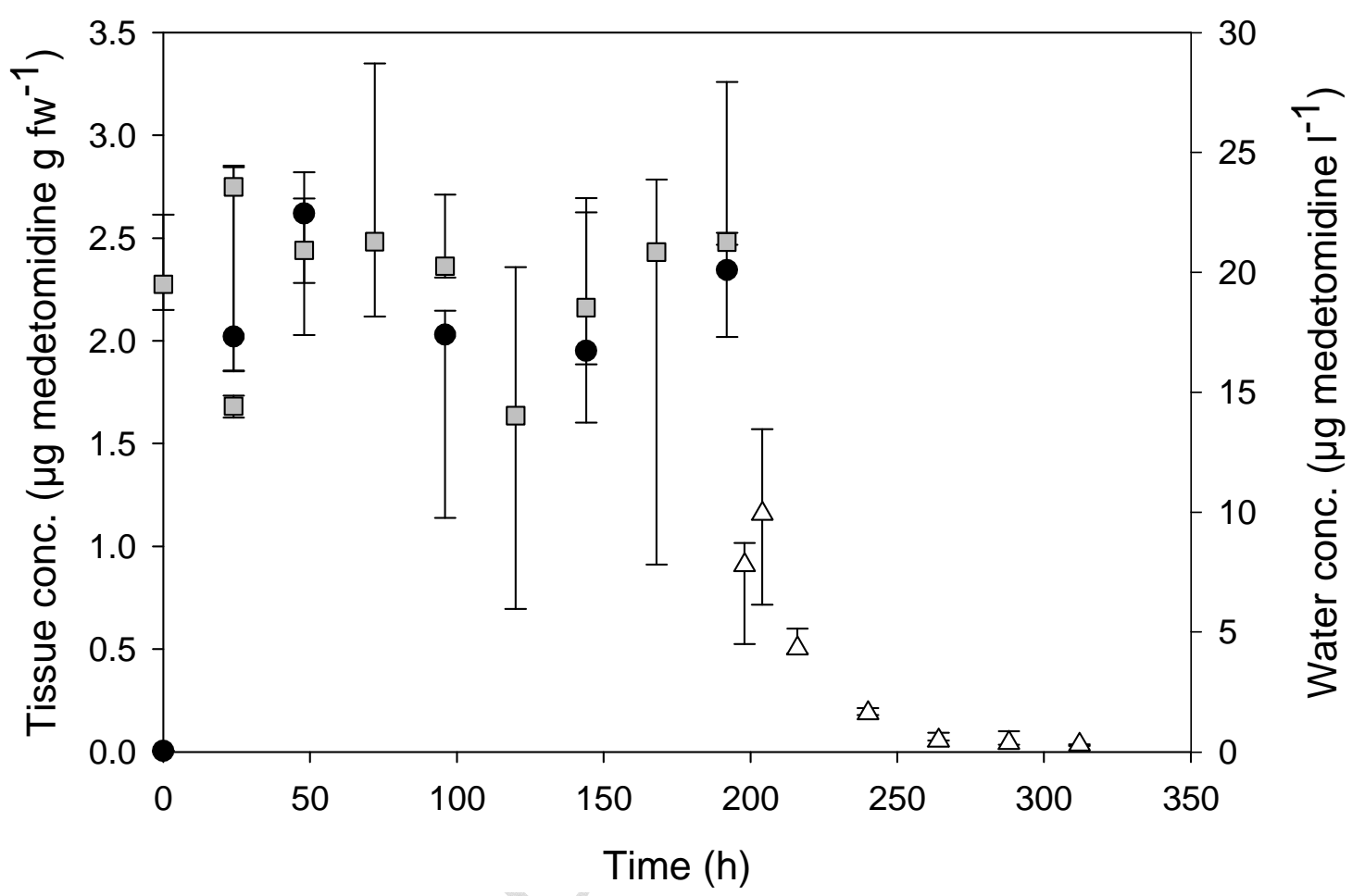


Figure 3

Figure 3

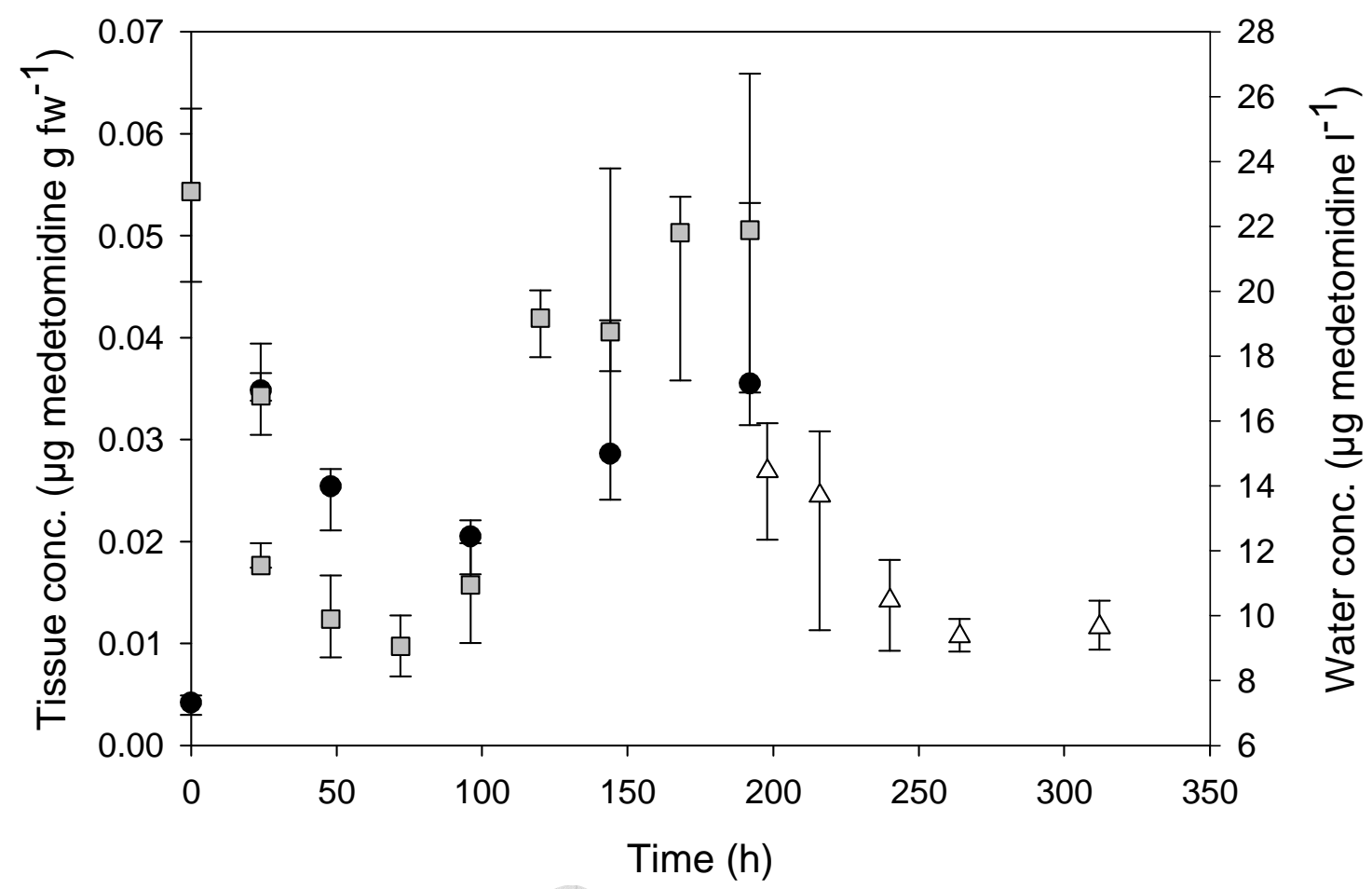


Figure 4

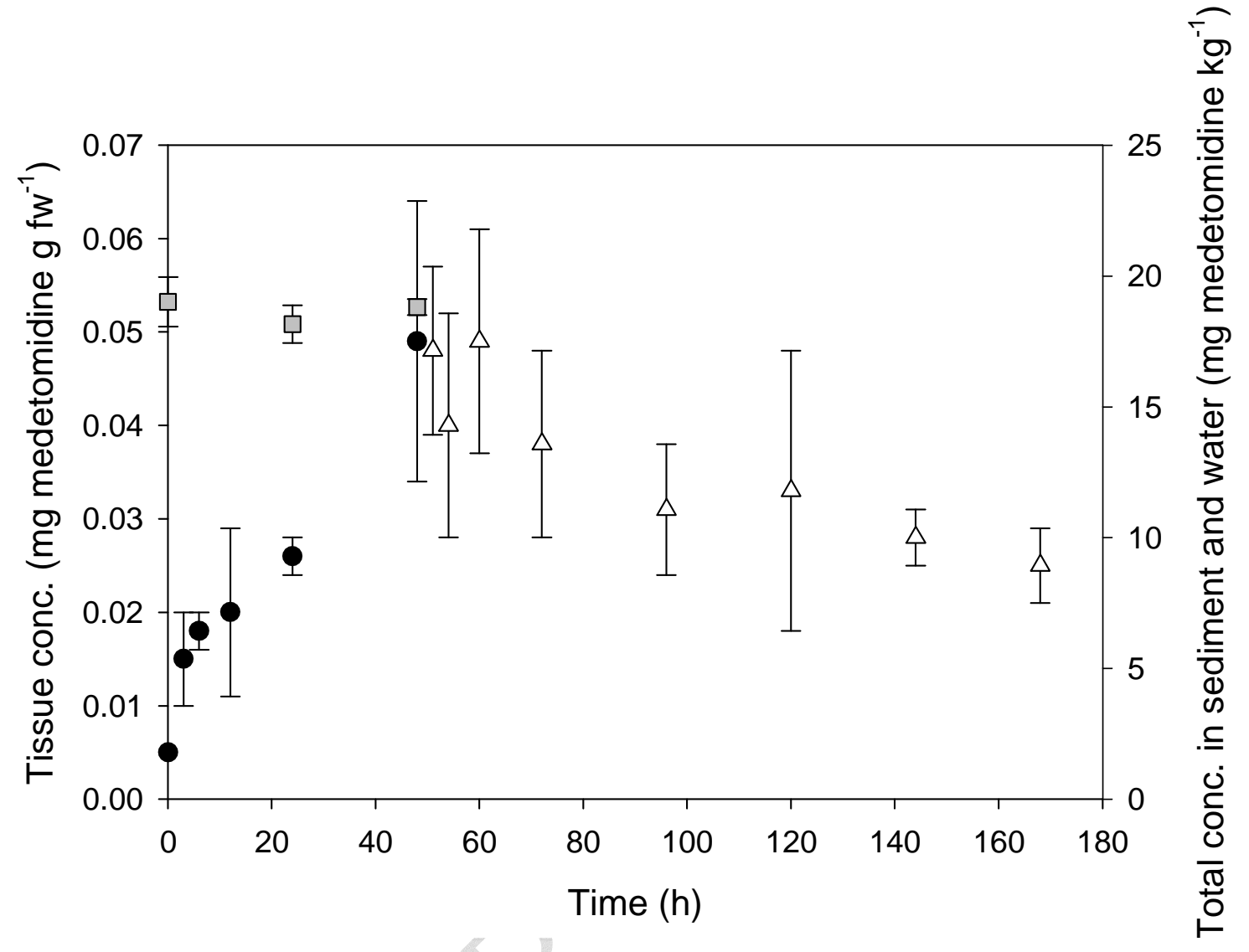


Figure 5

Figure 5

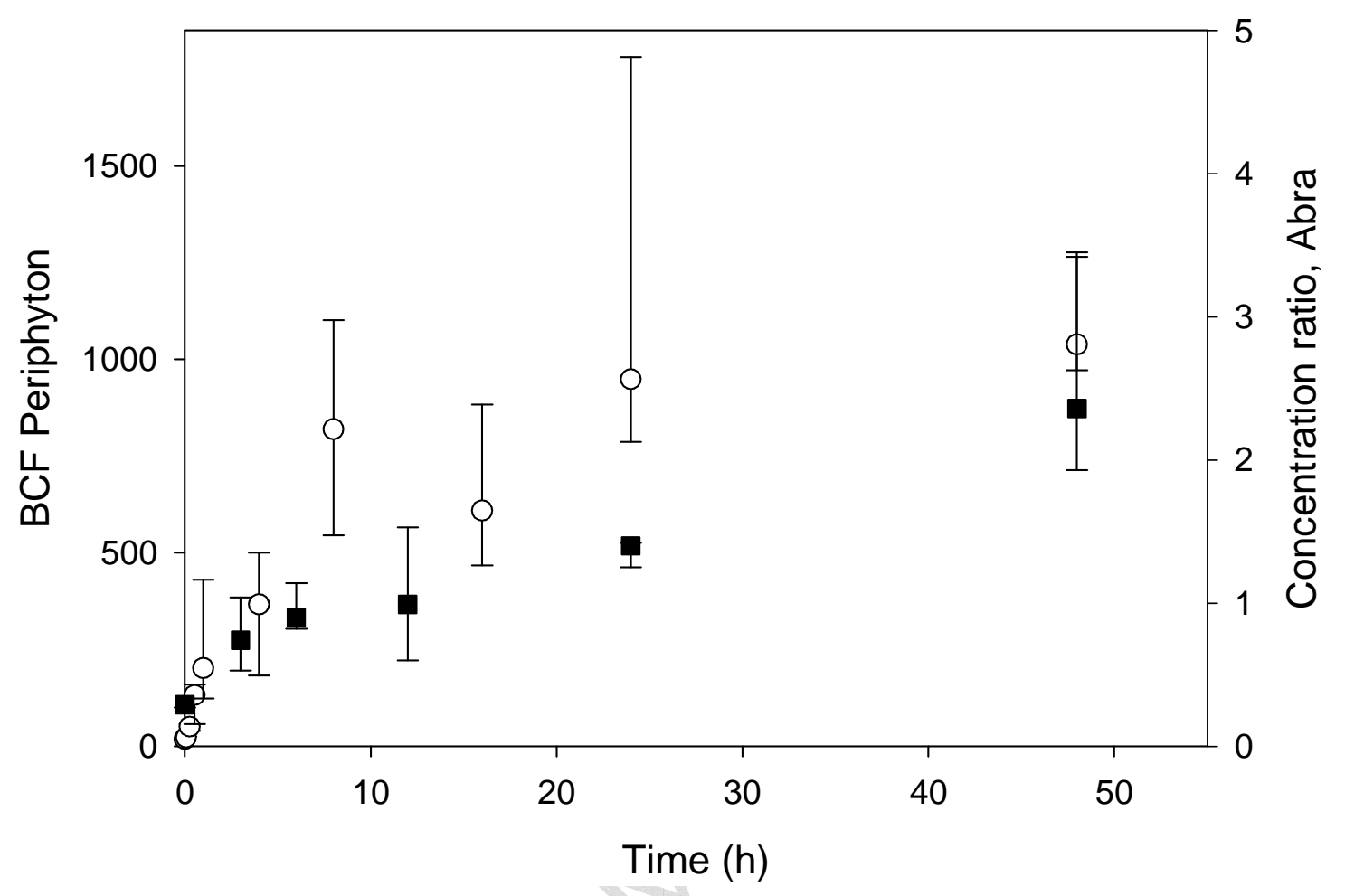


Figure 6

Figure 6

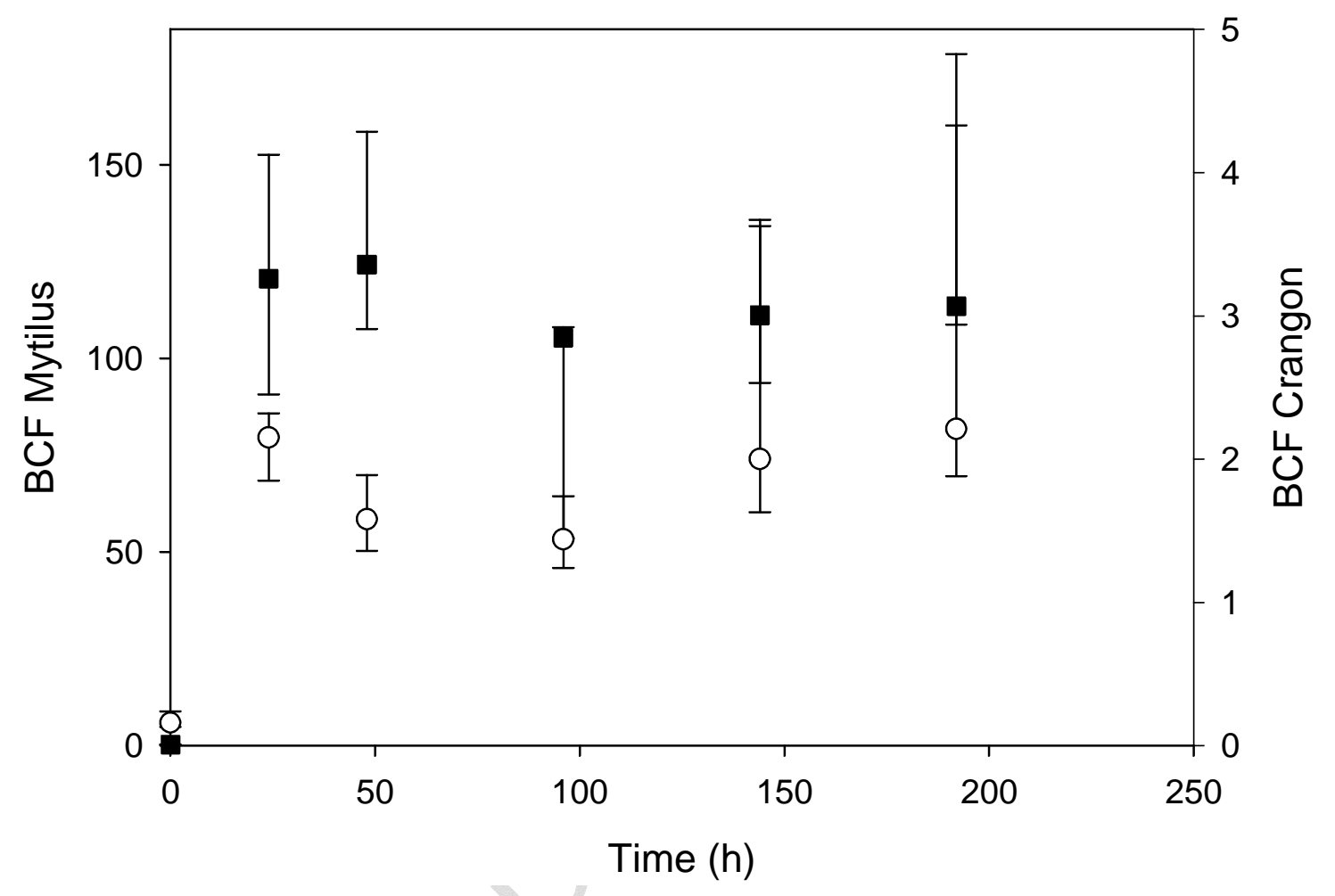

